\title{
Make Internationalism Great Again: The AIB in an Age of Populist Nationalism
}

\section{Stephen J. Kobrin, University of Pennsylvania, USA}

\begin{abstract}
The isolationist believes that we can build a wall around America and that democracy can live behind that wall, that America "can be made self-sufficient and still retain the free way of life. But the internationalist denies this. The internationalist declares that, to remain free, we must trade with one another - must trade freely in goods, in ideas, in customs and traditions and in values of all sorts." (Lewis, 2018: 195)
\end{abstract}

Most AIB members would agree that international economic, social, cultural, and political cooperation can contribute to a better world and that cross-border exchanges should be encouraged. At this point, however, that sentiment is far from universal: the very values and mission of the AIB are under attack in many of our countries from economic nationalists such as Trump in the United States, BREXIT supporters in Britain, Orban in Hungary, and most recently, Bolsonaro in Brazil.

Wendell Willkie's ${ }^{1}$ strong affirmation of internationalism was delivered in June 1941 as much of the world was being consumed by World War II. To a large extent, the war was a reaction to, and a result of, the events of the 1930s: the Great Depression destroyed the world economy, international transactions ground to a halt, and the very viability of capitalism and democracy were questioned. Italian or German fascism and Russian communism were seen as the future: preferable alternatives to the stagnation of parliamentary democracies, the failure of liberal economies, and the ill effects of globalization. During the interwar period, the international economy was rudderless: in Charles Kindleberger's (1986) words, the UK was unable and the US unwilling to exert leadership.

The reemergence of illiberal populist nationalism, character- ized by an antipathy to foreign trade and investment - and foreigners in general - raises some critical questions for AIB members. In this essay I will ask:

Is globalization and an open and integrated international economy, the norm, or an exception? Does technological progress require that the international economy be organized globally? Are other reasonably efficient modes of international economic organization possible?

Is it possible to have an open international system - economic, political, and social - that allows for a degree of national independence acceptable to most countries? Can a viable international system based on the rule of law be constructed that allows for the very wide diversity in national polities and economies present in the world today? Is it possible for China's state capitalism, European social democracy (or what is left of it), and American neo-liberalism to be subsumed within a single global system?

My intention is to raise questions and stimulate discussion rather than attempting answers.

\section{Is Globalization Inevitable?}

From the earliest days of our field, there has been a sense of inevitability in many of our analyses of globalization. Raymond Vernon began his seminal book by declaring, "[S] uddenly, it seems, the sovereign states are feeling naked. Concepts such as national sovereignty and national economic strength appear curiously drained of meaning" (Vernon, 1971: 3). I, and others, have argued that globalization fundamentally compromised sovereignty and geographic jurisdiction (Kobrin, 2001), 
and that the revolution in technology and the demands of efficiency make increasing international economic and political integration inevitable.

That assumption of inevitability has been severely tested by impact of the Great Recession and the wide-spread populist reaction to globalization. In the modern era, there have been two "waves" of globalization: the first dating from the last third of the $19^{\text {th }}$ century to World War I, or more finally, the Great Depression, and the second arising in the late $20^{\text {th }}$ century, perhaps peaking with the Great Recession of 2007-08. The world economy slammed shut in 1930 with the Great Depression, and we may have experienced an ebb in the tide of globalization following the Great Recession.

That raises an important question: Are free flows of trade and investment - open borders and regulatory regimes - the normal state of affairs and economic nationalism a temporary reaction to specific circumstances such as widespread economic difficulties? Or, on the contrary, does an open international economy require an unusual and exceptional conjuncture of economic and political conditions - robust national economies, willing politicians, and perhaps a hegemonic power - which only occur infrequently?

This sense of inevitability has, to a large extent, been technologically driven. Thus, the first wave was a response to the $19^{\text {th }}$ century developments in transport and communication such as steam ships, the telegraph, and telephone. The second wave was a response to jet aircraft, container shipping and, most important, the digital revolution. Many of our analyses assume, at least implicitly, that technology is not merely an enabler of globalization but also a determinant of it. That as that no single country, even the largest, has the capacity to fully exploit the scale and complexity of $21^{\text {st }}$ century technology, an open and integrated international economy is a requisite rather than a choice. Thus, backing away from a global world economy would entail costs that citizens of many of our countries would be unwilling to absorb. That the costs of disintegration - e.g., of unraveling cross-border supply networks - would be too great to be politically tolerable. Unfortunately, the emerging trade wars of 2019 and their potential effect on supply chains may provide a natural test of this hypothesis.

Kindleberger's argument that a hegemon or dominant power is needed to stabilize the system bears directly on the question of inevitability. Hegemonic stability is essentially a public goods argument; it has been called the imperialism of free trade: without a dominant power large enough to benefit from an open economy regardless of the actions of others, and powerful enough to both order it and absorb its costs, the system cannot be maintained.

US leadership was critical to the organization of the international economic system after World War II and to its mainte- nance through the rest of the $20^{\text {th }}$ century. As America is losing both its dominant position and its interest in leadership, the system has begun to unravel. If the emergence of a hegemon who is both willing and able to organize and maintain a functioning international economic system is a necessary condition for economic openness, then that would lend credence to the argument that globalization is a function of fortuitous conditions. It might well be the exception rather than the norm.

To a large extent, American hegemony meant that the US created late $20^{\text {th }}$ century globalization in its own image: the neoliberalism of the Washington consensus which entailed a degree of laissez-faire economics not required by the circumstances (Kuttner, 2018). Dani Rodrik (2018) defined the recent round of globalization as hyperglobalization, the elimination of all transaction costs that might hinder trade and capital flows. The explicit form that globalization has taken may well reflect a political choice rather than an economic or technological necessity. The choice we face is one of degree rather than kind: the path that globalization should take, rather than the very existence of an integrated international economy. As Joseph Stiglitz argued, "there is no way that we can become fully "unglobalized”" (Stiglitz 2018: 75).

Thus, the question of whether globalization - an open international economy - is the norm or an aberration cannot be separated from the specific form that both waves of globalization have taken. The crisis of democracy and liberalism in the 1930s - the turn towards fascism and communism - was a reaction to the excess of the first wave of globalization, to the extreme and very harsh liberalism of the late $19^{\text {th }}$ century. Similarly, the populist reaction we are currently experiencing is, in part, a reaction to hyperglobalization and the Washington Consensus, a faith in unlimited markets and unrestrained ideological neo-liberalism. The critical question is not whether globalization is the norm or an aberration, but the alternative forms that a more equitable and sustainable globalization might take? I will return to this question shortly.

\section{Can the International Political- Economic System Be Maintained?}

While the post-War international system has evolved over time, two underlying assumptions have remained constant: it must be based on the rule of law and the market must be embedded in, at the least, some minimal set of societal institutions. In the last two decades those institutions have been the World Trade Organization, the International Monetary Fund, and the World Bank. At a minimum, there has been agreement on rules such as most favored nation and national treatment ( an international legal principle that requires equal treatment of foreigners and nationals). 
At this point, the international system is under siege, not in the least from powerful forces in the country most responsible for its construction. On the surface, the opposition would appear to be motivated by a populism and economic nationalism which distains binding international agreements and sees international economic relationships as a zero-sum game.

More substantively, changes in the nature of the system and its context underlie its erosion. The second wave of globalization entailed deep integration: foreign direct investment, integrated global supply chains, and digital networks that affected "behind the border" regulation and constrained national autonomy more directly than frontier regulations affecting trade. As, if not more, important the context - the nature of the countries comprising the system - has become increasingly heterogenous over time.

At its origin, the post-War system required agreement between European and North American liberal democracies, which despite their considerable differences - were more alike than not in terms of their market economies, democratic political systems, and respect for the rule of law. That has changed dramatically with the growth in economic importance of countries such as China with authoritarian polities and mixed state-market economies.

These trends raise two critical questions: first, can countries with very diverse domestic economic and political systems agree on a set of rules - and institutions to enforce them - to govern the international economy? Second, and related, can a single system based on the rule of law incorporate countries where the meaning of that term varies dramatically? The difficulty of answering both questions is exacerbated by the decline of US hegemony and the absence of a dominant power able and willing to exert leadership. We face a situation reminiscent of the late $19^{\text {th }}$ century of increasing conflict between a declining hegemon and a rising power, which did not end well.

At the height of the second wave of globalization, I (Kobrin, 1998) and a number of others argued that we were entering a period of systemic change in the world order comparable to the transition from the feudal to the modern era: a "neomedievalism" that would lead to the erosion of the post-Westphalian international state-based order. That the scale and complexity of technology and the emergence of electronically integrated global networks would render geographic borders and, more fundamentally, the basic construct of territorial sovereignty problematic. We were wrong.

As Rodrik (2018: 19) noted, the nation-state has refused to wither away in the face of globalization: "it has proved remarkably resilient and remains the main determinant of the global distribution of income, the primary locus of market-supporting institutions, and the chief repository of personal attach- ments and institutions." Territorial sovereignty has survived globalization and has roared back with a vengeance.

To an important extent, there was confusion with the US led imposition of what Kuttner (2018) has called radical laissez faire or fundamentalist neoliberalism on the international system with a real convergence of ideas and ideology. He noted that allowing duty free imports from countries with poor labor and environmental standards was a political choice and not an economic necessity. Similarly, the transition from Bretton Woods to the Washington consensus represented an ideological choice: a retreat from what John Ruggie (1982) has called "embedded liberalism," the idea that the economic system must be embedded in a social order.

While the Washington Consensus - deregulation, markets, and open borders - prevailed for a time in practice, it did not represent an underlying, substantive, ideological agreement. "In the years following the fall of the Iron Curtain, there may have been economic, financial, and to a degree, technological globalization, but there was globalization of neither institutions nor ideas" (King, 2017: 215).

Rodrik (2018: 27), echoing a line of argument that goes back to Karl Polanyi (2001), noted that markets must be embedded in nonmarket institutions: "[W]ell functioning, sustainable markets are backed by a wide range of institutions that provide the critical functions of regulation, redistribution, monetary and fiscal stability, and conflict management." While there has been considerable attention paid to the need for global governance in the literature (see Kobrin [2008] for references), it has been problematic to date, and as Stiglitz (2018) argued, it has been biased towards the interests of corporations.

Given the significant variation in political-economic beliefs and institutions cross-nationally, a global solution to Polanyi's problem - the necessity of re-embedding markets in society and social institutions - would seem to be beyond reach. However, that does not imply a stark choice between unfettered global markets and de-globalization.

As I have argued elsewhere (Kobrin, 2017), devolution of the world economy towards anything approaching national independence, much less autarchy, is not feasible. The costs of dismantling supply chains and replicating all of their stages domestically would not be acceptable to citizens of most countries. That said, the choice is not bipolar but a continuous trade-off between global integration and national political-economic control.

The problem is to find the balance between the extent of global economic integration and national control of institutions and regulation that provides the more important benefits of the former while allowing for a degree of freedom in the latter acceptable to most countries. A major constraint on any solution 
is that any international economic system has to be based on the rule of law, regardless of the variation in the character of the domestic polities which comprise it.

Given the experience of the last two decades, it is naïve to believe that a market economy and capitalism inevitably lead to liberal democracy. Any meaningful international economic system will have to include democracies and autocracies and market-based and state-based economies.

\section{Conclusion and Implications}

As Stiglitz, Rodrik, and other critics have noted, the answer is not deglobalization but a less extensive and intensive form of international integration that provides the more important benefits of an international economy while allowing for an acceptable degree of national choice. That raises questions such as, what international institutions are necessary to facilitate international economic exchange, and what are reasonable limits for international as opposed to domestic regulation? Can a diverse group of countries agree on a set of rules to govern international economic transactions? These questions are critically important and should be at the forefront of AIB members' research and discussion.

I have not dealt with the question of equity. The distributive effects of globalization on income and wealth were significant "with large groups being worse off unless countervailing measures were taken to share the gains, but these measures were seldom undertaken" (Stiglitz, 2018: xxiv). How the benefits of globalization can be more widely dispersed and the costs remediated is a critical topic that certainly must be addressed.

I began this essay by noting that I would pose questions rather than provide answers. Most AIB members are internationalists who believe that international economic, political, social, and cultural cooperation can contribute to a better world, and that national self-sufficiency will not lead to a better life. A challenge for us as individuals and as an organization is to take advantage of our expertise to contribute to the discussion and to help navigate between increasing calls for autarchy and national independence ("America First") on the one hand, and the unfettered globalization that has resulted in both waves crashing on the shoals of a hyper-nationalistic response, on the other. I would hope that we, collectively and individually, can rise to that challenge.

\section{References}

Kindleberger, C. P. 1986. The World in Depression, 1929-39. Berkeley, CA: The University of California Press.

King, S. D. 2017. Grave New World: The End of Globalization, The Return of History. New Haven, CT: Yale University Press.
Kobrin, S. J. 1998. "Back to the Future: Neomedievalism and the Postmodern Digital World Economy." Journal of International Affairs, 51 (2): 361-386.

Kobrin, S. J. 2001. Soverignty@Bay: Globalization, Multinational Enterprise and the International Political System. In T Brewer \& A. Rugman (Eds), Oxford Handbook of International Business: 181 205. Oxford: Oxford University Press.

Kobrin, S. J. 2008. Globalization, Transnational Corporations and the Future of Global Governance. In A. G. Scherer \& G. Plazzo (Eds), Handbook of Research on Corporate Citizenship: 249-272. Cheltenham: Edward Elgar.

Kobrin, S. J. 2017. Bricks and Mortar in a Borderless World: Globalization, the Backlash and Multinational Enterprise. Global Strategy Journal, 7(2): 159-171.

Kuttner, R. 2018. Can Democracy Survive Global Captialism? New York: W.W. Norton \& Company.

Lewis, D. L. 2018. The Improbable Wendell Willkie: The Businessman who Saved the Republican Party and His Country, and Conceived a New World Order. New York: Liveright Publishing Corporation.

Polanyi, K. 2001. The Great Transformation: The Political and Economic Origins of Our Time. Boston, MA: Beacon Press.

Rodrik, D. 2018. Straight Talk on Trade: Ideas for a Sane World Economy. Princeton, NJ: Princeton University Press.

Ruggie, J. G. 1982. International Regimes, Transactions and Chance: Embedded Liberalism in the Postwar Economic Order. International Organization, 36(2).

Stiglitz, J. E. 2018. Globalization and its Discontents Revisited: Anti-Globalization in the Age of Trump. New York: W. W. Norton and Company.

Vernon, R. 1971. Sovereignty at Bay. New York: Basic Books.

\section{Endinote}

1 Wendell Willkie was the failed Republican candidate for President in 1940 and a committed internationalist who was instrumental in overcoming American isolation prior to the US entry into WWII.

Stephen J. Kobrin (kobrins@wharton.upenn.edu) is William H. Wurster Professor of Multinational Management Emeritus at the Wharton School of the University of Pennsylvania. His research interests include globalization, global governance, global strategy, and the politics of international business. He has served as President of the Academy of International Business, Chair of the International Division of the Academy of Management and is a Fellow of AIB. 